\title{
AiMT
}

Advances in Military Technology

Vol. 12, No. 2 (2017), pp. 229-242

ISSN 1802-2308, eISSN 2533-4123

DOI 10.3849/aimt.01193

\section{Fire and False Fire Alarm Causes in Military Jet Aircraft of Czechoslovakia and the Czech Republic}

\author{
O. Zavila ${ }^{1 *}$ and R. Chmelík ${ }^{2}$ \\ ${ }^{1}$ Department of Fire Protection, VSB - Technical University of Ostrava, Czech Republic \\ ${ }^{2}$ Military Unit 7214, $211^{\text {th }}$ Squadron, Ćáslav, Czech Republic
}

The manuscript was received on 28 April 2017 and was accepted after revision for publication on 28 October 2017.

\begin{abstract}
:
The article deals with the causes of fires and false fire alarms in military jet fighter, fighter-trainer and trainer aircraft in service of Czechoslovakia and the Czech Republic in 1948-2015. It presents a list of fire and false fire alarm causes by aircraft types on a timeline as well as historical and technical contexts, facts and development trends of these causes. Importantly, the role of the human factor in the causes of fire and false fire alarm emergency occurrences is also analyzed. The study is accompanied by a unique overview of reference and information sources remaining accessible on the subject.
\end{abstract}

\section{Keywords:}

Army of the Czech Republic, Czechoslovak Army, Czechoslovak People's Army, false fire alarm, fire, jet aircraft, cause

\section{Introduction}

The profession of military pilot is different from other professions in many aspects. For military pilots to face challenges does not mean to overcome their physical or mental limits in an uncontrolled way; on the contrary, it means to perfectly recognize and respect such limits. This profession requires a great deal of personal physical and mental discipline. It is a profession that cannot be exercised with fear; however, one must have healthy respect and humbleness while maintaining a high degree of personal initiative to meet the target. Healthy aggressiveness complemented by a lot of courage, precision, consistency, concentration and perseverance are the characteristics of a good pilot with a long-term professional development perspective. To achieve the necessary concentration on the flight task, the pilot also needs to have some mental peace. Among other extremely important factors (such as family or working environment), the knowledge of the causes and consequences of aviation emergency occurrences also contribute to pilots' mental state. If there is an emergency situation on the

\footnotetext{
* Corresponding author: Department of Fire Protection, VSB - Technical University of Ostrava, Lumírova 13/630, CZ-700 30 Ostrava, Czech Republic. Phone: +420 597322893 , E-mail: ondrej.zavila@vsb.cz
} 
same type of aircraft technology or in the same air fleet in which the pilot serves and its causes remain undisclosed, it often gives rise to concerns among pilots that there might be some unknown factors or latent defects in the equipment. These concerns may weaken the concentration and indirectly contribute to a future aviation accident (hereinafter "AA") or a precondition for aviation accident (hereinafter "PAA").

In this context, the primary mission of this study is to bring a comprehensive overview of causes of AAs and PAAs related to the occurrence of a fire or a false fire alarm on board of military jet fighter, fighter-trainer and trainer aircraft in service of Czechoslovakia and the Czech Republic in 1948-2015. The study follows previous thematic studies (see [1]).

\section{Statistical Summary}

The statistical summary of emergency occurrences causally linked to a fire or a false fire alarm on board is divided into five tables (see Tab. 1-5 below) broken down by types of emergency occurrences. The classification of emergency occurrences is based on the contents of the Všeob-P-10 Flight Safety [3] regulation which was in force between 2006 and June 2016 and was replaced by the Order of the Ministry of Defence No. 13/2016 of the Journal - Flight Safety“ dated $15^{\text {th }}$ June, 2016 [4]. In this Order, however, substantial changes in definitions, terminology and classification of emergency occurrences in military aviation were made. Therefore, in order to effectively synchronize data from AAs and PAAs for different periods, the authors of this study chose the classification system based on the previous Všeob-P-10 Flight Safety regulation. Most of available technical literature and archival records are based on the contents of this Všeob-P-10 Flight Safety regulation, including the information base from the Information System for Logistics (hereinafter "ISL") [5], a part of which has been used by the Air Force of the Army of the Czech Republic (hereinafter "AF ACR") to keep records of emergency occurrences since 1985 to the present day.

The tables below can be principally divided into two groups. The first group contains the summary of emergency occurrences causally linked to fire (see Tab. 1-4), while the second group contains the summary of emergency occurrences causally linked to false fire alarms (see Tab. 5). In accordance with the Všeob-P-10 Flight Safety regulation, the aviation emergency occurrences are divided into disasters (see Tab. 1), air crashes (see Tab. 2), damage (see Tab. 3) and preconditions for aviation accident (see Tab. 4-5).

To get a picture of particular emergency occurrences, each table shows the aircraft type, number of occurrences for each aircraft type, main cause of the occurrence and phase of the flight in which the problem incurred by the main cause became evident. Dash "-" indicates that data is not available or that the entry equals to zero.

The column "Aircraft type" in each table lists only basic designation of the aircraft type; for ease of reference, version designations are left out.

The column "Number of occurrences" in each table lists the total number of occurrences of a particular AA or PAA type for the aircraft type between 1948 and 2015. The proportion of occurrences of particular AA or PAA type for the aircraft type in relation to the total number of occurrences is shown in parenthesis.

The column "Main cause" in each table lists the classification of occurrences into one of four groups of main causes: technical factor ("TF"), human factor ("HF"), environmental factor ("EF") and not found ("N"). The human factor is subdivided into flight personnel ("fp") and non-flight personnel ("np"). 
Tab. 1 Summary of disasters causally linked to on-board fires in 1948-2015 (aircraft types ranked according to the number of occurrences) [5-18]

\begin{tabular}{|c|c|c|c|c|c|c|c|c|c|c|c|c|c|c|c|}
\hline \multirow{3}{*}{$\begin{array}{l}\text { Aircraft } \\
\text { type }\end{array}$} & \multirow{3}{*}{$\begin{array}{l}\text { Number of } \\
\text { occurrences }\end{array}$} & \multicolumn{5}{|c|}{ Main cause } & \multicolumn{9}{|c|}{ Phase of flight } \\
\hline & & \multirow[b]{2}{*}{ TF } & \multicolumn{2}{|c|}{ HF } & \multirow[b]{2}{*}{ EF } & \multirow[b]{2}{*}{$\mathbf{N}$} & \multirow[b]{2}{*}{1} & \multirow[b]{2}{*}{2} & \multirow[b]{2}{*}{3} & \multirow[b]{2}{*}{4} & \multirow[b]{2}{*}{5} & \multirow[b]{2}{*}{6} & \multirow[b]{2}{*}{7} & \multirow[b]{2}{*}{8} & \multirow[b]{2}{*}{9} \\
\hline & & & fp & np & & & & & & & & & & & \\
\hline MiG-15 & $4(40 \%)$ & 2 & 1 & 1 & - & 1 & - & - & 1 & 2 & 1 & - & - & - & - \\
\hline MiG-21 & $2(20 \%)$ & 1 & 1 & - & - & - & - & - & - & 1 & - & - & 1 & - & - \\
\hline MiG-19 & $1(10 \%)$ & 1 & - & - & - & - & - & - & 1 & - & - & - & - & - & - \\
\hline Il-28 & $1(10 \%)$ & - & - & - & - & 1 & - & - & 1 & - & - & - & - & - & - \\
\hline L-29 & $1(10 \%)$ & 1 & - & - & - & - & - & - & 1 & - & - & - & - & - & - \\
\hline L-39 & $1(10 \%)$ & 1 & - & - & - & - & - & - & - & 1 & - & - & - & - & - \\
\hline Total & $10(100 \%)$ & 6 & 2 & 1 & - & 2 & - & - & 4 & 4 & 1 & - & 1 & - & - \\
\hline
\end{tabular}

Tab. 2 Summary of air crashes causally linked to on-board fires in 1948-2015

(aircraft types ranked according to the number of occurrences) [5-18]

\begin{tabular}{|c|c|c|c|c|c|c|c|c|c|c|c|c|c|c|c|}
\hline \multirow{3}{*}{$\begin{array}{c}\text { Aircraft } \\
\text { type }\end{array}$} & \multirow{3}{*}{$\begin{array}{l}\text { Number of } \\
\text { occurrences }\end{array}$} & \multicolumn{5}{|c|}{ Main cause } & \multicolumn{9}{|c|}{ Phase of flight } \\
\hline & & \multirow[b]{2}{*}{ TF } & \multicolumn{2}{|c|}{ HF } & \multirow[b]{2}{*}{ EF } & \multirow[b]{2}{*}{$\mathbf{N}$} & \multirow[b]{2}{*}{1} & \multirow[b]{2}{*}{2} & \multirow[b]{2}{*}{3} & \multirow[b]{2}{*}{4} & \multirow[b]{2}{*}{5} & \multirow[b]{2}{*}{6} & \multirow[b]{2}{*}{7} & \multirow[b]{2}{*}{8} & \multirow[b]{2}{*}{9} \\
\hline & & & fp & np & & & & & & & & & & & \\
\hline MiG-15 & $24(40 \%) *$ & 12 & 5 & 3 & - & 2 & 3 & 6 & 3 & 6 & 1 & - & 1 & 4 & - \\
\hline MiG-21 & $16(26.7 \%)$ & 10 & 2 & 1 & 2 & 1 & 1 & 3 & 2 & 6 & 1 & - & 2 & 1 & - \\
\hline MiG-19 & $6(10 \%)$ & 1 & - & 2 & 1 & 2 & 1 & - & 1 & 3 & - & - & 1 & - & - \\
\hline L-39 & $5(8.3 \%)$ & 5 & - & - & - & - & - & - & - & 5 & - & - & - & - & - \\
\hline L-29 & $4(6.6 \%)$ & 3 & - & - & 1 & - & - & 1 & 1 & 2 & - & - & - & - & - \\
\hline Su-7 & $2(3.3 \%)$ & 1 & 1 & - & - & - & - & 1 & - & 1 & - & - & - & - & - \\
\hline Il-28 & $1(1.7 \%)$ & - & - & - & - & 1 & - & 1 & - & - & - & - & - & - & - \\
\hline MiG-23 & $1(1.7 \%)$ & - & - & - & - & 1 & - & - & - & 1 & - & - & - & - & - \\
\hline $\mathrm{Su}-22$ & $1(1.7 \%)$ & 1 & - & - & - & - & - & - & - & 1 & - & - & - & - & - \\
\hline Total & $60(100 \%)$ & 33 & 8 & 6 & 4 & 7 & 5 & 12 & 7 & 25 & 2 & - & 4 & 5 & - \\
\hline
\end{tabular}

* Documents to identify the main cause of the crash are not available for 2 out of the 60 crashes.

Tab. 3 Summary of damage causally linked to on-board fires in 1948-2015 (aircraft types ranked according to the number of occurrences) [5-18]

\begin{tabular}{|c|c|c|c|c|c|c|c|c|c|c|c|c|c|c|c|}
\hline \multirow{3}{*}{$\begin{array}{c}\text { Aircraft } \\
\text { type }\end{array}$} & \multirow{3}{*}{$\begin{array}{l}\text { Number of } \\
\text { occurrences }\end{array}$} & \multicolumn{5}{|c|}{ Main cause } & \multicolumn{9}{|c|}{ Phase of flight } \\
\hline & & \multirow[b]{2}{*}{ TF } & \multicolumn{2}{|c|}{ HF } & \multirow[b]{2}{*}{$\mathbf{E F}$} & \multirow[b]{2}{*}{$\mathbf{N}$} & \multirow[b]{2}{*}{1} & \multirow[b]{2}{*}{2} & \multirow[b]{2}{*}{3} & \multirow[b]{2}{*}{4} & \multirow[b]{2}{*}{5} & \multirow[b]{2}{*}{6} & \multirow[b]{2}{*}{7} & \multirow[b]{2}{*}{8} & \multirow[b]{2}{*}{9} \\
\hline & & & fp & np & & & & & & & & & & & \\
\hline MiG-19 & $4(33.3 \%)$ & 4 & - & - & - & - & - & 1 & - & 1 & - & - & 1 & 1 & - \\
\hline MiG-21 & $3(25 \%)$ & 1 & 1 & 1 & - & - & - & 1 & - & 1 & - & 1 & - & - & - \\
\hline MiG-15 & $2(16.7 \%)$ & 1 & 1 & - & - & - & - & 1 & - & 1 & - & - & - & - & - \\
\hline L-39 & $2(16.7 \%)$ & - & - & - & - & 2 & - & - & - & 2 & - & - & - & - & - \\
\hline Su-7 & $1(8.3 \%)$ & 1 & - & - & - & - & 1 & - & - & - & - & - & - & - & - \\
\hline Total & $12(100 \%)$ & 7 & 2 & 1 & - & 2 & 1 & 3 & - & 5 & - & 1 & 1 & 1 & - \\
\hline
\end{tabular}

In the "Phase of flight" column in each table, the phase of flight in which the emergency situation was first detected is indicated: before take-off ("1"), take-off (“2”), climb (“3”), flight task (“4”), arrival (“5”), approach maneuvering (“6”), landing (“7”), after landing (“8”) and unknown (“9”). 
Tab. 4 Summary of preconditions for aviation accidents causally linked to on-board fires in 1948-2015 (aircraft types ranked according to the number of occurrences) [5-18]

\begin{tabular}{|c|c|c|c|c|c|c|c|c|c|c|c|c|c|c|c|}
\hline \multirow{3}{*}{$\begin{array}{c}\text { Aircraft } \\
\text { type }\end{array}$} & \multirow{3}{*}{$\begin{array}{l}\text { Number of } \\
\text { occurrences }\end{array}$} & \multicolumn{5}{|c|}{ Main cause } & \multicolumn{9}{|c|}{ Phase of flight } \\
\hline & & \multirow[b]{2}{*}{ TF } & \multicolumn{2}{|c|}{ HF } & \multirow[b]{2}{*}{ EF } & \multirow[b]{2}{*}{$\mathbf{N}$} & \multirow[b]{2}{*}{1} & \multirow[b]{2}{*}{2} & \multirow[b]{2}{*}{3} & \multirow[b]{2}{*}{4} & \multirow[b]{2}{*}{5} & \multirow[b]{2}{*}{6} & \multirow[b]{2}{*}{7} & \multirow[b]{2}{*}{8} & \multirow[b]{2}{*}{9} \\
\hline & & & fp & np & & & & & & & & & & & \\
\hline MiG-21 & $5(33.3 \%)$ & 4 & - & - & - & 1 & - & - & 1 & - & - & - & - & 4 & - \\
\hline JAS-39 & $5(33.3 \%)$ & - & - & - & - & 5 & - & - & - & - & - & - & - & 5 & - \\
\hline Su-7 & $3(20 \%)$ & 1 & - & 1 & - & 1 & - & 1 & - & - & - & - & - & 2 & - \\
\hline MiG-15 & $2(13.4 \%)$ & 2 & - & - & - & - & 1 & - & - & - & - & 1 & - & - & - \\
\hline Total & $15(100 \%)$ & 7 & - & 1 & - & 7 & 1 & 1 & 1 & - & - & 1 & - & 11 & - \\
\hline
\end{tabular}

Tab. 5 Summary of preconditions for aviation accidents causally linked to on-board false fire alarms in 1948-2015 (aircraft types ranked according to the number of occurrences) [5-18]

\begin{tabular}{|c|c|c|c|c|c|c|c|c|c|c|c|c|c|c|c|}
\hline \multirow{3}{*}{$\underset{\text { type }}{\text { Aircraft }}$} & \multirow{3}{*}{$\begin{array}{l}\text { Number of } \\
\text { occurrences }\end{array}$} & \multicolumn{5}{|c|}{ Main cause } & \multicolumn{9}{|c|}{ Phase of flight } \\
\hline & & \multirow[b]{2}{*}{ TF } & \multicolumn{2}{|c|}{ HF } & \multirow[b]{2}{*}{ EF } & \multirow[b]{2}{*}{$\mathbf{N}$} & \multirow[b]{2}{*}{1} & \multirow[b]{2}{*}{2} & \multirow[b]{2}{*}{3} & \multirow[b]{2}{*}{4} & \multirow[b]{2}{*}{5} & \multirow[b]{2}{*}{6} & \multirow[b]{2}{*}{7} & \multirow[b]{2}{*}{8} & \multirow[b]{2}{*}{9} \\
\hline & & & $f p$ & $\mathrm{np}$ & & & & & & & & & & & \\
\hline MiG-21 & $34(52.3 \%)$ & 18 & - & 3 & 7 & 6 & - & 5 & 7 & 20 & 1 & 1 & - & - & - \\
\hline MiG-23 & $12(18.5 \%)$ & 4 & - & - & 4 & 4 & - & 1 & 1 & 9 & 1 & - & - & - & - \\
\hline L-29 & $10(15.4 \%)$ & 8 & - & - & 1 & 1 & - & - & 2 & 5 & 3 & - & - & - & - \\
\hline Su-25 & $5(7.7 \%)$ & 2 & - & - & 2 & 1 & - & - & 1 & 4 & - & - & - & - & - \\
\hline MiG-15 & $2(3.1 \%)$ & 2 & - & - & - & - & - & - & 1 & 1 & - & - & - & - & - \\
\hline Su-22 & $1(1.5 \%)$ & - & - & 1 & - & - & - & - & - & 1 & - & - & - & - & - \\
\hline L-39 & $1(1.5 \%)$ & 1 & - & - & - & - & - & - & - & 1 & - & - & - & - & - \\
\hline Total & $65(100 \%)$ & 35 & - & 4 & 14 & 12 & - & 6 & 12 & 41 & 5 & 1 & - & - & - \\
\hline
\end{tabular}

\section{Causes, Interesting Facts, Contexts and Development Trends}

A total of 162 aviation emergency occurrences (82 AAs of various types and 80 PAAs) were traced and analyzed for this study.

The aviation emergency occurrences can be divided into two groups. The first group is composed of aviation emergency occurrences causally linked to a fire on board an aircraft: 10 disaster AAs, 60 crash AAs, 12 damage AAs and 15 PAAs. The second group is composed of 65 PAAs representing aviation emergency occurrences causally linked to false fire alarms on board. The causes and contexts for both groups of aviation emergency occurrences are dealt with in the following paragraphs (see sections 3.1 to 3.6 ).

\subsection{Causes of Fires - Disaster AAs}

A total of 10 AAs recorded as disasters causally linked to the occurrence of a fire on board were traced (see Tab. 1). In 6 cases, there were 7 unsuccessful ejections (twoman crew was in one of the aircraft). In 6 out of these 7 unsuccessful ejections, the fail resulted from ejecting at too low an altitude and in one case, even though the ejection altitude was sufficient, the parachute failed to open due to incorrect fastening of parachute harness straps. In one case, the pilot correctly completed an emergency landing but then he was unable to leave the cockpit and died in a fire. In the remaining three cases the crew did not even make an attempt to eject. 
The main causes of this type of aviation disasters include technical factors (6 cases) and human factors ( 3 cases); in one case the cause was not found. As for the human factor, flight personnel error ( 2 cases) prevails over non-flight personnel error (1 case).

The most critical time of the year appears to be April (3 disasters) and August (2 disasters). Other months of the year when the other disasters of this type took place over the course of 36 years (between 1955 and 1991 when disasters of this type were recorded) include June, July, September, November and December. More detailed breakdown of disaster AAs can be found in [1].

As for a phase of flight when for the first time a problem emerged resulting in a disaster of this type, "climb" phase (4 cases - see section 2, phase of flight no. 3 in tables) and "flight task" phase (4 cases - see section 2, phase of flight no. 4 . in tables) were found to be the most frequent.

The main causes of aviation disasters of this type can be generally associated with failures in aircraft fuel and hydraulic equipment, mechanical destruction to engine components (compressor impellers and turbine disks), thermal damage to the engine, and flight and non-flight personnel errors.

The causes falling under flight personnel error involved a collision with a sleeve target for live air target practice and erroneous landing planning.

The non-flight personnel error involved an omission by a repairer in the Aircraft Repair Works Malešice (in Czech Letecké Opravny Malešice, hereinafter "LOM") who during turbine reassembly after defectoscopy had taken place failed to secure a lock ring, which resulted in bursting of the turbine disk during the flight.

\subsection{Causes of Fires - Air Crash AAs}

A total of 60 AAs recorded as air crashes causally linked to the occurrence of a fire on board were traced (see Tab. 2). In 27 cases, there were 31 successful ejections (twoman crew was in four of the aircraft). In the remaining 33 cases the crew did not even make an attempt to eject.

The main causes of this type of aviation disasters include technical factors (33 cases), human factors (14 cases) and environmental factors (4 cases); in 7 cases the cause was not found. Out of 60 air crashes of this type, records to indicate the air crash main causes were no longer available in 2 cases (MiG-15bis crash of $1^{\text {st }}$ April, 1959, and UTI MiG-15 crash of $7^{\text {th }}$ September, 1962). As for the human factor, flight personnel error ( 8 cases) prevails over non-flight personnel error (6 cases).

The most critical time of the year appears to be April and September ( 8 air crashes each), June, July and October (6 air crashes each) and then January, March and August ( 5 air crashes each). Other months of the year when the other air crashes of this type took place over the course of 56 years (between 1954 and 2010 when air crashes of this type were recorded) include February, May and November. More detailed breakdown of air crash AAs can be found in [1].

As for a phase of flight when for the first time a problem emerged resulting in an air crash of this type, "flight task" phase (25 cases - see section 2, phase of flight no. 4 in tables) and "take-off" phase (12 cases - see section 2, phase of flight no. 2 in tables) were found to be the most frequent.

The main causes of air crashes of this type can be generally associated with failures in aircraft fuel and hydraulic installations, mechanical damage or destruction to parts of drive units (for example, see Fig. 1), weapon system malfunctions (e.g. LR-55 
missile premature destruction in front of the MiG-15SB of $5^{\text {th }}$ February, 1962, or the NR-30 cannon barrel destruction during shooting followed by fuel tank perforation in the Su-22M-4 of $19^{\text {th }}$ September, 1989), flight and non-flight personnel errors, and adverse conditions related to the airfield environment.

Some interesting cases of air crashes falling under technical factors were events known as "titanium fires". Titanium fires were fires in 1991-2010 in C and ZA versions of the L-39s with AI-25 TL and AI-25 TLM engines with rear rotor labyrinth of high-pressure compressor made of titanium. When flight or aerobatic manoeuvres were performed with vertical load over $3 \mathrm{~g}$, the rotor and the stator (casing) of the double rear labyrinth of the high-pressure compressor could come into contact with each other which resulted in the ignition of the titanium alloy the rotor was made of. The fire spread out and damaged other engine components near to where the fire originated.
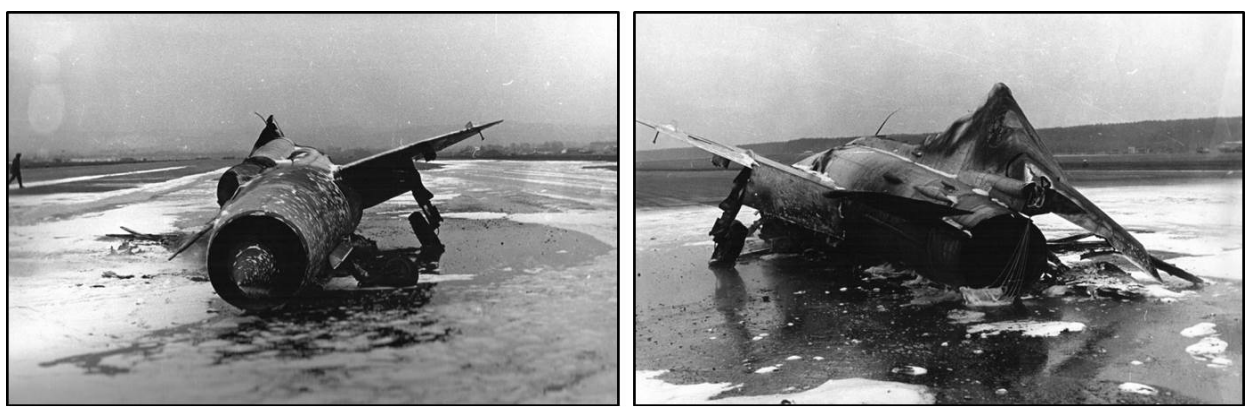

Fig. 1 MiG-21PFM air crash, fuselage number 5408, of $6^{\text {th }}$ January, 1972 [13]

The causes falling under flight personnel error specifically involved: faulty landing of overloaded aircraft resulting in damage to a fuel tank, landing with retracted landing gear resulting in damage to fuel tanks, taking off with premature retraction of the landing gear before lift-off resulting in damage to fuel tanks and controls, uncoordinated intervention in the directional control of the airplane in an attempt to capture the released canopy rear cover during take-off resulting in a collision with an obstacle, and non-compliance with procedures for emergency engine restart in flight resulting in a flashover of the initiated excess fuel in the engine which the pilot wrongly assessed as a fire and ejected.

The causes falling under non-flight personnel error specifically involved: a foreign object in the rear of the engine resulting in a fire during take-off, neglected check of the landing gear emergency air system valve resulting in a rupture of the hydraulic vessel due to the air overpressure from that system during landing gear retraction after take-off, misconduct of aviation engineering services members resulting in a return valve leak in the intake of air to additional fuel tanks and subsequent fire, neglected check of fuel tank overpressure by technicians resulting in an engine fire during engine test, unauthorized removal of the hydraulic valve reinforcement resulting in a fire of hydraulic fluid leaked through a crack onto the engine, and violation of rules for aircraft fuelling by the technical staff resulting in technical difficulties at fuel transfer during flight task and in engine speed drop. It is an interesting fact that in the latter case, the aircraft, after the pilot had ejected, glided down in an uncontrolled flight and landed on the airfield where it burned down after the fuel initiation (the MiG-21F crash of $26^{\text {th }}$ September, 1977). 
The causes falling under environmental factors specifically involved: poor condition of runways causing damage to landing gears and resulting in a fire at landing, high humidity in the cockpit causing electrical short circuits or burning of the insulation and wires, and collisions with birds (gulls, partridges) causing critical drop in thrust and engine fire at taking off.

\subsection{The Causes of Fires - Damage AAs}

A total of 12 AAs recorded as damage causally linked to the occurrence of a fire on board were traced (see Tab. 3). In 1 case, there was 1 successful ejection (in two-man crew, one pilot ejected from the forward cockpit during an emergency landing). In the remaining 11 cases the crew did not make an attempt to eject.

The main causes of this type of aviation damage include technical factors ( 7 cases) and human factors ( 3 cases); in 2 cases the cause was not found (for example, see Fig 2). As for the human factor, flight personnel error (2 cases) prevails over non-flight personnel error (1 case).
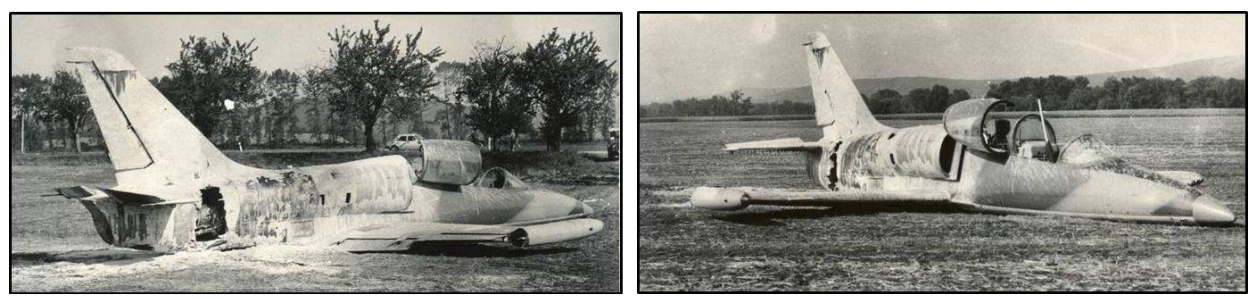

Fig. 2 Damage to the L-39C, fuselage number 0110, of 24 th August, 1988 [13]

The most critical time of the year appears to be August ( 8 cases) and May ( 2 cases). Other months of the year when the other damage events of this type took place over the course of 26 years (between 1962 and 1988 when damage events of this type were recorded) include January, March, April, June and July. More detailed breakdown of damage AAs can be found in [1].

As for a phase of flight when for the first time a problem emerged resulting in damage of this type, "flight task" phase ( 5 cases - see section 2, phase of flight no. 4 in tables) and "take-off" phase ( 3 cases - see section 2, phase of flight no. 2 in tables) were found to be the most frequent.

The main causes of damage events of this type can be generally associated with failures in aircraft fuel and hydraulic installations, mechanical destruction to engine components (compressor impellers), failures in the jet engine exhaust nozzle operation, defects in landing gear wheel tires, and flight and non-flight personnel errors.

The causes falling under flight personnel error specifically involved pilot errors connected with unintentional retraction of the landing gear at taking off resulting in a fire caused by rubbing of the fuselage bottom against the runway.

The non-flight personnel error involved an omission by a repairer in LOM who inappropriately secured a blind on a fuel supply pipe leading into the afterburner collectors which resulted later in a fire when the afterburner was activated.

\subsection{Causes of Fires - PAAs}

A total of 15 PAAs causally linked to the occurrence of a fire on board were traced (see Tab. 4). 
The main causes of this type of PAA include technical factors (7 cases) and human factors ( 1 case); in seven cases the cause was not found. As for the human factors, only error of non-flight personnel occurred.

The most critical time of the year appears to be June (4 PAAs) and July (4 PAAs). Other months of the year when the other PAAs of this type took place over the course of 46 years (between 1966 and 2012 when PAAs of this type were recorded) include January, March, April, August and December. More detailed breakdown of PAAs can be found in [1].

As for a phase of flight when for the first time a problem emerged resulting in a PAA of this type, "after landing" phase (11 cases - see section 2, phase of flight no. 8 in tables) was found to be the most frequent.

The main causes of PAAs of this type can be generally associated with failures in aircraft fuel, oil and hydraulic installations, defects in landing gear wheel tires, and non-flight personnel errors.

The causes falling under human errors - this time only by non-flight personnel specifically involved an omission by an aircraft technician who failed to close caps in fuselage and wing fuel tanks and the leaking fuel caught fire from afterburner flame during taking off.

It should be noted that for 3 out of those 7 cases where the main cause was recorded as "not found", probable scenarios of the PAA occurrences had been defined. In one case that took place in December 1976, it was probably an error on the part of the pilot of the MiG-21F caused by an incorrect manipulation with the engine control lever after landing. The engine stopped too early and the pilot tried to restart it with the engine control lever, which led to the ignition of the excess fuel in a still hot engine discharge nozzle. Another two cases occurred in June 2006 and these were fires of wheels on the JAS-39C's main landing gear caused probably by an ignition of grease or its residues mixed with carbon dust during after-landing braking.

\subsection{Causes of False Fire Alarms - PAAs}

A total of 65 PAAs causally linked to a false fire alarm on board an aircraft were traced (see Tab. 5).

The main causes of this type of PAAs include technical factors (35 cases), environmental factors (14 cases) and human factors ( 4 cases); in 12 cases the cause was not found. As for the human factors, only error of non-flight personnel occurred.

The most critical time of the year appears to be April (11 PAAs), then January, March, May and June (7 PAAs each), and October (6 PAAs). Other months of the year when the other PAAs of this type took place over the course of 26 years (between 1975 and 2000 when PAAs of this type were recorded) include February, July, August, September, November and December.

As for a phase of flight when for the first time a problem emerged resulting in a PAA of this type, "flight task" phase (41 cases - see section 2, phase of flight no. 4 in tables) and "climb" phase (12 cases - see section 2, phase of flight no. 3 in tables) were found to be the most frequent.

The main causes of PAAs of this type can be generally associated with failures of components of fire protection and hydraulic installations, electrical short circuits, blowing of hot gasses from the engine onto fire detectors due to a mechanical failure in one of the technical systems located nearby, excess humidity near fire detectors, and non-flight personnel errors. 
The causes falling under environmental factors specifically involved mainly humidity and dirt close to the fire detectors or fire signalling units that created electrically conductive environment and caused an unwanted activation. This would occur mostly after periods of rainy weather when the aircraft were not sufficiently protected from rain (e.g. on alert) or sometimes when flying through clouds.

The causes falling under human errors - again only by non-flight personnel specifically involved: an overlooked oil dispensing trigger blind stuck in a fire detector compartment and causing a short circuit of the detectors and fire alarm activation, an overlooked piece of securing wire causing a short circuit between fire detector cable socket and airframe, an omitted securing wire for hydraulic valve torn off and randomly short-circuiting fire signalization unit wire, and an omitted tether loosened from a cap to plug outlet hole for discharging oil from the lower engine reducer causing again a short circuit of a fire detector.

For 2 out of 12 cases where the main cause was recorded as "not found", probable scenarios of the PAA occurrences had been defined. In both cases, the cause was most likely some temporary humidity in the space where fire detectors were located due to changing weather conditions.

\subsection{Summary of AA and PAA Causes, Contexts and Development Trends}

In sum, main causes of fires and false fire alarms on board of military jet aircraft are highly varied. No main causes that would characterize specific aircraft types could be reasonably defined for any of the investigated AAs and PAAs. They are series of emergency occurrences that do not show any global logical system over time (see Fig. 3 and Fig. 4) or by an aircraft type. Nevertheless, some exceptions and interesting facts can be observed, e.g. among the disaster and air crash AAs causally linked to the occurrence of a fire on board. They are represented by the L-39s in versions C and ZA where the phenomenon known as "titanium fires" occurred in 1991-2010 (see section 3.2 above). Another exception can be observed among PAAs in the JAS-39s version C where a series of small landing gear fires during after-landing breaking occurred in 2006-2012 due to previously unknown reasons (see section 3.4 above). Weapon system malfunctions causing in-flight fires in 1962 and 1989 are also noteworthy (see section 3.2 above).

Some exceptions to the rule stated above can be found also among PAAs causally linked with false fire alarms. One is the L-29 where a typical defect consisting in blowing hot air or gases onto a fire detector due to a damaged sealing of the $6^{\text {th }}$ combustion chamber of the engine. The other one is frequent negative effect of humidity on the function of thermo-differential and ionization fire detectors recorded mostly from the early 1970s to the mid-1990s in the MiG-21s, MiG-23s and Su-25s.

The analysis of causes of AAs and PAAs of the types mentioned also shows that the general development trend in flight safety is towards minimization of all groups of factors to which the causes of such AAs and PAAs can be attributed.

This has been best attained with the improvement of technical conditions. The introduction of turbofan engines whose external parts are "cold" compared to the previously used turbojets was a significant contribution [19]. In former Czechoslovakia they started to be used in the early 1970s with the L-39s and have continued until these days in the MiG-29s, L-159s and JAS-39s. If there is damage to any of the aircraft systems associated with a leakage of a flammable liquid onto these external parts of the engines, the fire risk is lower. Progress has been made also in the development of 


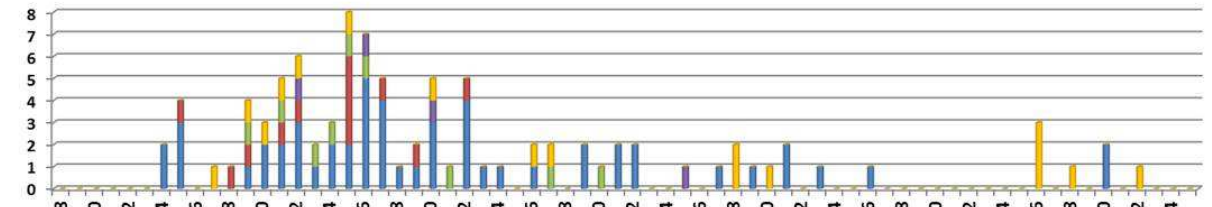

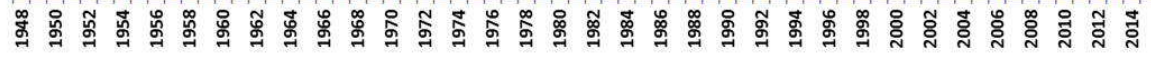

$=\mathrm{TF} \equiv \mathrm{HF}-\mathrm{fp} \equiv \mathrm{HF}-\mathrm{np} \equiv \mathrm{EF} \equiv \mathrm{N}$

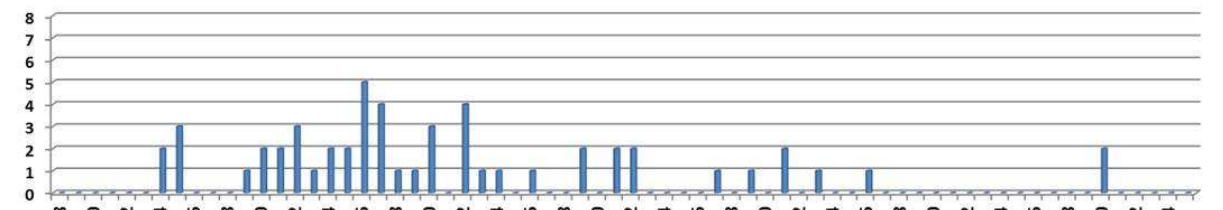

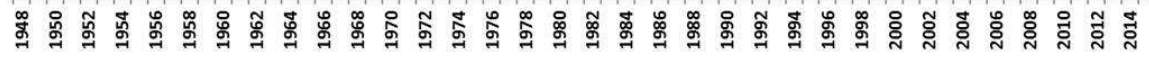

IIF

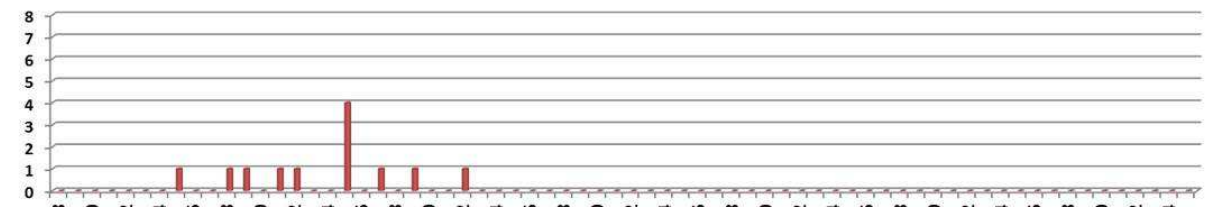

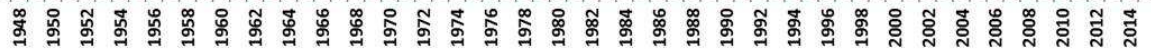

$=H F-f p$

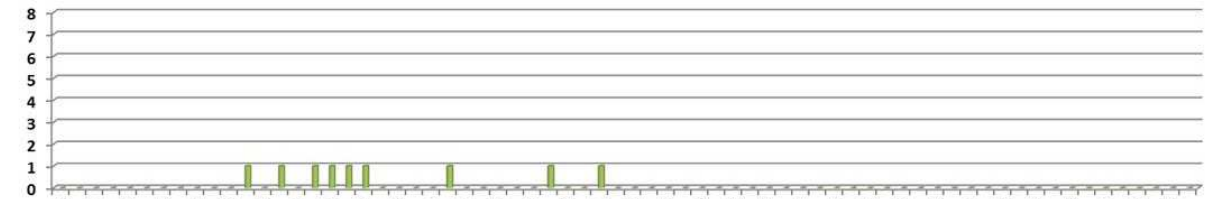

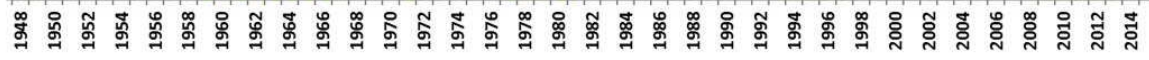

$=\mathrm{HF}-\mathrm{np}$
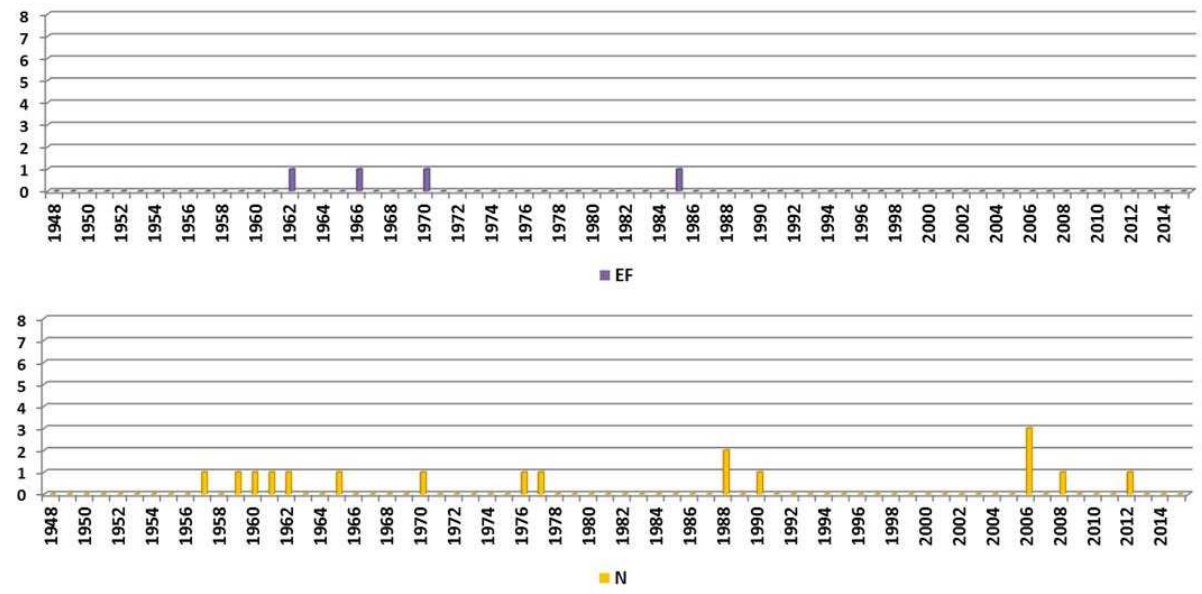

Fig. 3 Graphical overview of the total and partial number of the main causes of fires in 1948-2015 [5-18] 
Fire and False Fire Alarm Causes in Military Jet Aircraft of Czechoslovakia and the Czech Republic

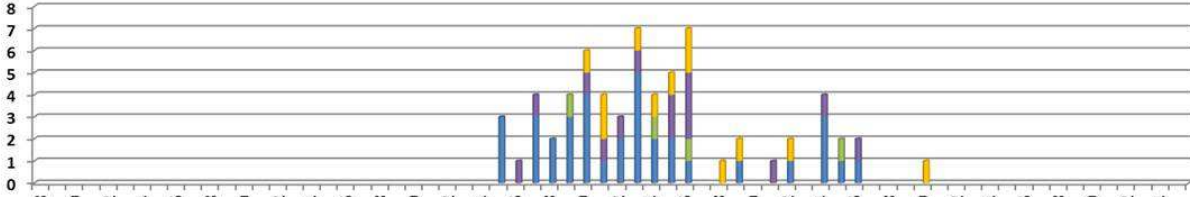

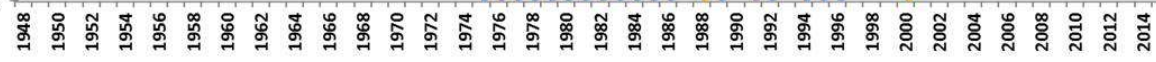

$\equiv \mathrm{TF} \equiv \mathrm{HF}-\mathrm{fp}=\mathrm{HF}-\mathrm{np} \equiv \mathrm{EF} \equiv \mathrm{N}$

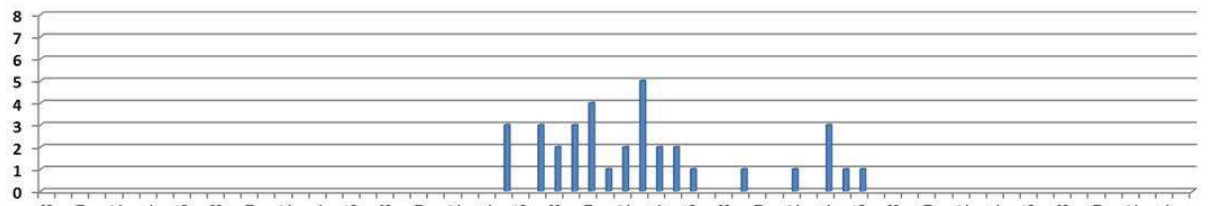

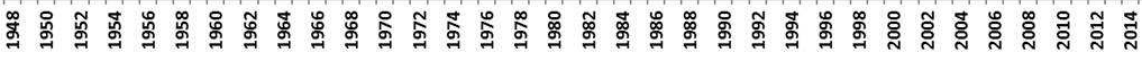

iㅏ TF

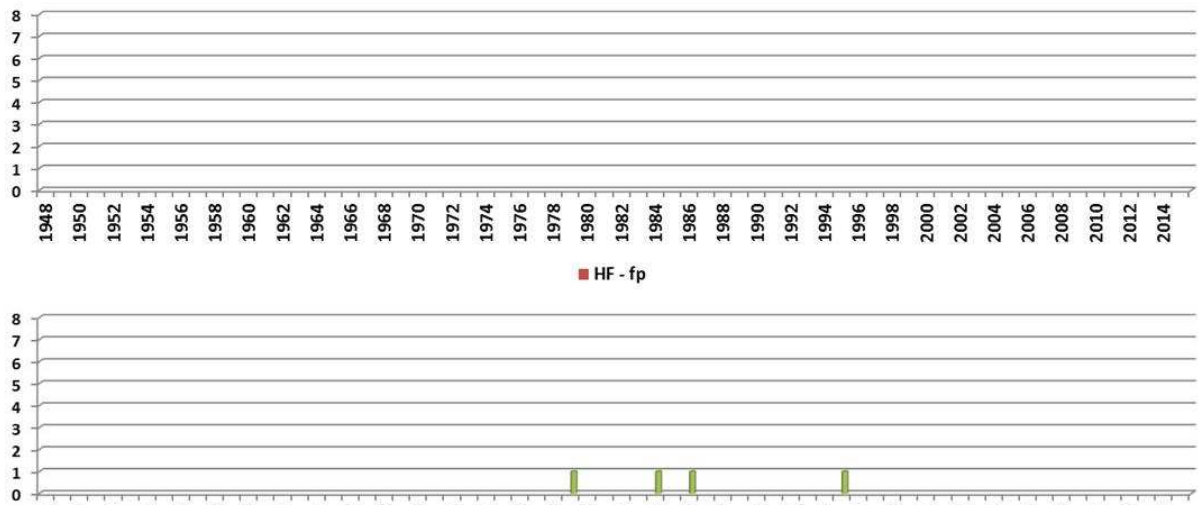

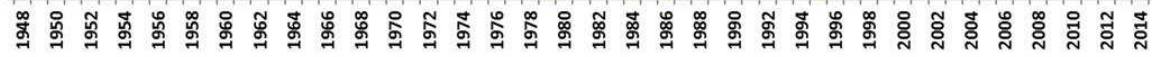

$=\mathrm{HF}-\mathrm{np}$
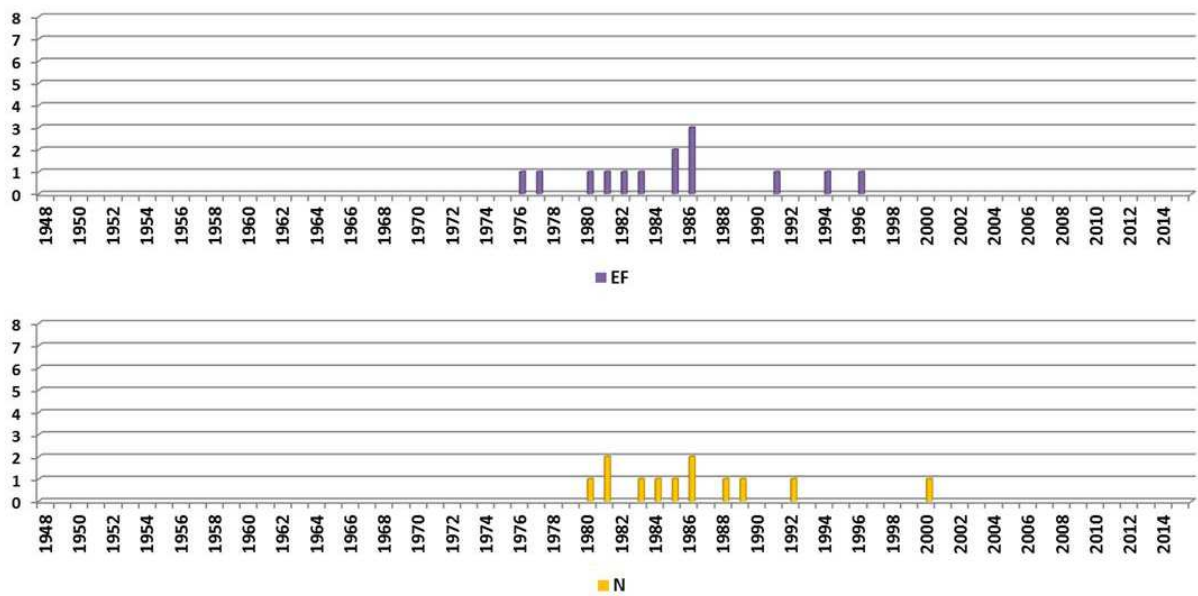

Fig. 4 Graphical overview of the total and partial number of the main causes of false fire alarms in 1948-2015 [5-18] 
fire detectors. In contrast to previously used bimetallic, thermo-differential and then ionization fire detectors, the current linear fire detectors are designed in such a way that their functioning is not so easily affected by humidity or foreign objects.

Minimization of the human factor as a main cause of AAs and PAAs has been less successful, as the human factor has its own limits which are yet unknown in the field of science.

The least success can be seen in environmental factors because they stay practically the same over time (i.e. erratic - weather, collisions with birds, etc.). For the contributions of different main causes to different types of AAs and PAAs, see Tab. 6 .

Tab. 6 Number and percentage of different main causes of different types of AAs and PAAs causally linked to fires or false fire alarms in 1948-2015 [5-18]

\begin{tabular}{|l|c|c|c|c|c|c|}
\hline \multirow{2}{*}{ Type of AA or PAA } & \multirow{2}{*}{ TF } & \multicolumn{2}{|c|}{ HF } & & \\
\cline { 3 - 6 } & fp & np & EF & N & Untraceable \\
\hline AA - disaster (fire) & 6 & 2 & 1 & 0 & 1 & 0 \\
Total 10 events (100\%) & $(60 \%)$ & $(20 \%)$ & $(10 \%)$ & $(0 \%)$ & $(10 \%)$ & $(0 \%)$ \\
\hline AA - air crash (fire) & 33 & 8 & 6 & 4 & 7 & 2 \\
Total 60 events (100\%) & $(55 \%)$ & $(13.3 \%)$ & $(10 \%)$ & $(6.7 \%)$ & $(11.7 \%)$ & $(3.3 \%)$ \\
\hline AA - damage (fire) & 7 & 2 & 1 & 0 & 2 & 0 \\
Total 12 events (100\%) & $(58.3 \%)$ & $(16.7 \%)$ & $(8.3 \%)$ & $(0 \%)$ & $(16.7 \%)$ & $(0 \%)$ \\
\hline PAA (fire) & 7 & 0 & 1 & 0 & 7 & 0 \\
Total 15 events (100\%) & $(46.7 \%)$ & $(0 \%)$ & $(6.7 \%)$ & $(0 \%)$ & $(46.7 \%)$ & $(0 \%)$ \\
\hline PAA (false fire alarm) & 35 & 0 & 4 & 14 & 12 & 0 \\
Total 65 events (100\%) & $(53.8 \%)$ & $(0 \%)$ & $(6.2 \%)$ & $(21.5 \%)$ & $(18.5 \%)$ & $(0 \%)$ \\
\hline Total: & $\mathbf{8 8}$ & $\mathbf{1 2} \%$ & $\mathbf{1 3}$ & $\mathbf{1 8}$ & $\mathbf{2 9}$ & $\mathbf{2}$ \\
\hline 162 events (100\%) & $(\mathbf{5 4 . 3} \%)$ & $\mathbf{( 7 . 4 \% )}$ & $(\mathbf{8} \%)$ & $(\mathbf{1 1 . 1} \%)$ & $(\mathbf{1 7 . 9} \%)$ & $(\mathbf{1 . 2} \%)$ \\
\hline
\end{tabular}

\section{Conclusion}

The aim of this study was to gather and systemize all information remaining accessible on the causes of fires and false fire alarms in military jet fighter, fighter-trainer and trainer aircraft in service of Czechoslovakia and the Czech Republic in 1948-2015. The gained knowledge and insights may serve not only as a summary of scenarios of selected emergency occurrences of this type, but also as a collection of arguments why in-flight fire emergencies should still be trained by flight crews and preventive safety principles strictly followed.

Finally, this and other similar studies can be a source of information on the development of trends in main causes of AAs and PAAs that can be used as a basis for updating or even change in flight training priorities. Formerly dominant technical factors as AA and PAA main causes are becoming less relevant, as the importance of human and environmental factors, minimization of which is a complex and forthcoming challenge for science, is increasing.

\section{Acknowledgment}

The authors would like to thank Lt. Col. Miroslav Němec, Lt. Col. Karel Valvoda, Col. Petr Chamrad, Mr. Miroslav Irra, Mr. Libor Režňák, Lt. Col. (Ret.) František Pisch, Maj. (Ret.) Lubomír Juriš and $1^{\text {st }}$ Lt. Karel Burger for their help, valuable advice, observations and comments on this work. 


\section{References}

[1] ZAVILA, O., CHMELÍK, R. and DOPATEROVÁ, M. Statistics of Aviation Accidents and Preconditions for Aviation Accidents in Czechoslovak and Czech Military Jet Aircraft: Fire. Advances in Military Technology, 2016, vol. 11, no. 2, p. 211-226.

[2] ZAVILA, O. Developments in the Classification of Aviation Accidents in Czechoslovak and Czech Military Aviation. Advances in Military Technology, 2017, vol. 12, No. 1, p. 5-20.

[3] Flight Safety [regulation V̌̌eob-P-10] (in Czech). 2006.

[4] Flight Safety (in Czech) [Order of the Minister of Defence No. 13/2006 of the Journal]. 2016.

[5] AURA, s.r.o. Information System for Logistics of Ministry of Defence and the Army of the Czech Republic (ISL) [software], [cited 2017-03-01].

[6] IRRA, M. Ilyushin Il-28: The Ilyushin Il-28 in Czechoslovak Air Force (Bilingual English / Czech publication). Nevojice: Jakab, 2013, 128 p. ISBN 97880-87350-12-6.

[7] IRRA, M. MiG-15: Vol. 3. (Bi-lingual English / Czech publication). Nevojice: Jakab, 2007, 96 p. ISBN 978-80-87161-01-2.

[8] IRRA, M. The Mikoyan-Gurevich MiG-19 in Czechoslovak Air Force (in Czech). Nevojice: Jakab, 2014, 128 p. ISBN 978-80-87350-15-7.

[9] IRRA, M. The "Twenty-one": The MiG-21 in Czechoslovak and Czech Air Force 1962-2005: Vol. 2. (Bi-lingual English / Czech publication). Nevojice: Jakab, 2008, 112 p. ISBN 978-80-87161-04-3.

[10] IRRA, M. Aero L-29 “Dolphin”: Vol. 2. Nevojice: Jakab, 2016. ISBN 978-8087350-34-8.

[11] REŽŇÁK, L. The Silver Jet MiG-15: Jet Beginnings of the Czechoslovak Air Force 1950-1957 (in Czech). Cheb: Svět křídel, 2012, 567 p. ISBN 978-80-87567-14-2.

[12] REŽŇÁK, L. The Steel Stallion MiG-19 and the Czechoslovak Air Force 19581972 (in Czech). Cheb: Svět křídel, 2008, 582 p. ISBN 978-80-86808-45-1.

[13] Military Central Archives: Homepage. Military Central Archives: Homepage [online]. Praha, 2010 [cited 2017-03-01]. Available from:

$<$ http://www.vuapraha.cz>

[14] SLAVÍK, S. Overview of Aviation Accidents, Serious Preconditions and Preventive Experience (Book 1) (in Czech). Hradec Králové, 1979.

[15] SLAVÍK, S. Overview of Aviation Accidents, Serious Preconditions and Preventive Experience (Book 2) (in Czech). Hradec Králové, 1979.

[16] SLAVÍK, S. Overview of Aviation Accidents, Serious Preconditions and Preventive Experience (Book 3) (in Czech). Hradec Králové, 1981.

[17] SLAVÍK, S. Overview of Aviation Accidents, Preconditions and Preventive Experience 1981-1982 (in Czech). Hradec Králové, 1986.

[18] SLAVÍK, S. Overview of Aviation Accidents, Preconditions, Deficiencies and Preventive Experience 1983-84 (in Czech). Hradec Králové, 1989. 
[19] HOCKO, M. Aircraft turbo-compressor engines used in the Czechoslovak aviation, part 1 - Aircraft turbo-compressor engines used in military aircrafts (in Slovak) [Learning Material]. Prešov: Technical University of Košice, 2000, 358 p. 